\begin{tabular}{|ll|}
\hline Received & $:$ 30 September 2019 \\
Revised & $:$ 1 Oktober 2019 \\
Accepted & $:$ 22 Oktober 2019 \\
Online & $: 25$ Oktober 2019 \\
Published & $: 29$ Oktober 2019 \\
\hline
\end{tabular}

\title{
POTENSI TEH BUNGA TELANG (Clitoria ternatea) SEBAGAI OBAT PENGENCER DAHAK HERBAL MELALUI UJI MUKOSITAS
}

\author{
Aisyah Denta Kusuma ${ }^{1)}$ \\ ${ }^{1}$ Fakultas Matematika dan Ilmu Pengetahuan Alam, Universitas Negeri Jakarta \\ email: aisyahaishimaru@gmail.com
}

\begin{abstract}
Abstrak
Asma adalah gangguan inflamasi kronik pada saluran pernapasan yang dapat terjadi pada individu baik anak-anak hingga dewasa yang rentan inflamasi dengan gejala mengi yang berulang, sesak napas, dada terasa tertekan, dan batuk sebagai akibat dari terbatasnya udara yang masuk ke paru-paru. Tujuan penelitian ini adalah mengetahui potensi kandungan teh kembang telang (Clitoria ternatea) sebagai alternatif obat pengencer dahak bagi penderita asma. Penelitian ini menggunakan metode penelitian eksperimen, dimana dalam penelitian ini diselidiki aktivitas mukolitik teh bunga telang, keadaan, kondisi, ataupun hal lain, yang kemudian dipaparkan dalam bentuk laporan penelitian. Data pada penelitian ini diperoleh dari hasil uji mukolitik seduhan teh bunga telang terhadap mukus sapi. Hasil dari penelitian ini ialah larutan teh telang memiliki potensi aktivitas mukolitik pada konsentrasi $30 \% \mathrm{~V} / \mathrm{v}$ sehingga konsumsi rutin berpotensi dapat membantu mengencerkan dahak dikarenakan terdapat penurunan laju alir mukus setelah penambahan larutan teh bunga telang serta terdapat kesamaan antara mukus sapi dengan dahak manusia.
\end{abstract}

Kata Kunci: Asma, Teh Bunga Telang, Clitoria Ternatea, Uji Mukositas

\begin{abstract}
Asthma is a chronic inflammatory disorder in the respiratory tract that can occur in both children and adults who are susceptible to inflammation with symptoms of recurrent wheezing, shortness of breath, chest pressure, and coughing as a result of the limited air entering the lungs. The purpose of this study was to determine the potential content of butterfly pea tea (Clitoria ternatea) as an alternative medication to loosening mucus for asthmatics. This study uses an experimental research method, where in this study investigated the mucolytic activity of butterfly pea tea, conditions, conditions, or other things, which are then presented in the form of a research report. The data in this study were obtained from the results of mucolytic test of butterfly pea tea steeping on cow mucus. The results of this study are butterfly pea tea solution having mucolytic activity potential at a concentration of $30 \% \mathrm{v} / \mathrm{v}$ so that regular consumption can potentially help thin the phlegm due to a decrease in mucous flow rate after the addition of butterfly pea tea solution and there are similarities between cow mucus and human sputum.
\end{abstract}

Keywords: Asma, Butterfly Pea Tea, Clitoria Ternatea, Uji Mukositas

\section{PENDAHULUAN}

Bunga telang (Clitoria ternatea) merupakan bunga yang dapat tumbuh sebagai tanaman hias maupun tanaman liar dengan kelopak tunggal berwarna ungu. Selain sebagai tanaman hias, sejak dulu 
bunga telang dikenal secara tradisional sebagai obat untuk mata, dan pewarna makanan yang memberikan warna biru. Belakangan ini bunga telang juga sedang ramai dikonsumsi di seluruh dunia akibat dari tren teh bunga yang populer melalui sosial media di Inggris dengan sebutan Butterfly Pea Tea (Andriani, 2016)

Dilihat dari tinjauan fitokimia, bunga telang memiliki sejumlah bahan aktif yang memiliki potensi farmakologi. Potensi farmakologi bunga telang antara lain adalah sebagai antioksidan, antibakteri, anti inflamasi dan analgesik, antiparasit dan antisida, antidiabetes, anti-kanker, antihistamin, immunomodulator, dan potensi berperan dalam susunan syaraf pusat (Budiasih, Kun Sri. 2017). Bagian lain dari tanaman ini yaitu akar dan batang juga dikenal memiliki potensi tersendiri sebagai obat tradisional.

Bunga telang (Clitoria ternatea) merupakan tanaman yang dapat ditemui tumbuh liar atau sebagai tanaman hias. Tanaman yang memiliki warna biru ini memiliki nama yang berbeda-beda di setiap daerah di Indonesia, seperti di daerah Sumatera disebut bunga biru, bunga kelentit, bunga telang, di Jawa disebut kembang teleng, menteleng, di Sulawesi disebut bunga talang, bunga temen raleng, dan di Maluku disebut bisi, seyamagulele (Dalimartha, 2008). Tanaman ini merupakan tanaman perdu tahunan yang memiliki perakaran yang dalam dan berkayu dengan kelopak bunga berwarna biru-ungu hingga hampir putih (Sutedi, 2013)

Bunga telang memiliki potensi farmakologis yang luas. Di dalam bunga telang terkandung tanin, flobatanin, karbohidrat, saponin, triterpenoid, fenolmfavanoid, flavanol glikosida, protein, alkaloid, antrakuinon, antisianin, stigmasit 4-ena-3,6 dion, minyak volatil dan steroid. Komposisi asam lemak dalam bunga telang meliputi asam palmitat, stearat, oleat lonoleat, dan linolenat. Kemudian dalam biji bunga telang juga mengadung asam sinamat, finotin dan beta sitosterol (Budiasih, 2017). Pada bagian akarnya terdapat kandungan beberapa turunan zat steroid, saponin, beberapa turunan zat flavonoid, dan glikosida (Taur \& Patil., 2011).

Flavonoid merupakan kandungan aktif yang terdapat dalam sejumlah obat tradisional, contohnya bunga telang dan putri malu. Zat ini dapat menghambat aktivasi IL-5 sehingga jumlah eosinofil dan pada tubuh akan enzim proteolitik berkurang sehingga hipertropi otot polos bronkiolus akan berkurang dan menyebabkan perbaikan gambaran histopatologi paru. Selain itu, flavonoid dapat memblokir transkripsi NF-Kb yang diinduksi oleh bakteri Phorphyromonas gingivali, menghambat IL-12, dan ekspresi TNF-alfa melalui sel epitel dan sel dendritik sehingga meminimalisir sel-sel sitokin dan kemokin yang mencapai permukaan lumen melalui epitel saluran penafasan sehingga mencegah kerusakan sel epitel dan terjadinya respon inflamasi (Rizki \& Hariandja, 2015). Pada percobaan flavonoid yang terkandung pada tanaman kelor, zat ini juga memiliki aktivitas merelaksasi otot polos dan sebagai bronkodilator (Mehta \& Agrawal, 2008).

Saponin dalam berbagai literatur juga mendukung aktivitas anti-asma. Glikosida saponin disebut dapat menstabilkan sel mast dalam percobaan tanaman kelor yang digunakan sebagai anti-asma (Thakur \& Verma, 2013). Saponin memiliki efek anti inflamasi serta menjaga sel dengan menghambat sekresi histamin, bradikinin, dan serotonin (Okechukwu \& Ekeuku, 2012). Peran saponin ini yang kemudian dapat mengurangi efek pembengkakan saluran pernapasan yang menjadi penyebab asma.

Dilihat dari tinjauan fitokimia, bunga telang memiliki sejumlah bahan aktif yang memiliki potensi farmakologi. Potensi farmakologi bunga telang antara lain adalah sebagai antioksidan, antibakteri, anti inflamasi dan analgesik, antiparasit dan antisida, antidiabetes, antikanker, antihistamin immunomodulator, dan potensi berperan dalam susunan syaraf pusat (Budiasih, 2017). Ekstrak bunga telang memiliki banyak khasiat sehingga digunakan sebagai obat tradisional untuk beberapa penyakit. Ekstrak tersebut dipercaya dapat menurunkan tekanan darah, anti kecemasan, anti asma, dan penghilang rasa sakit, dan anti tumor (Suganda dan Adhi. 2017).

Pada penderita asma dahak atau mukus diproduksi secara berlebihan sehingga menghalangi saluran napas pada saat gejala-gejala asma terjadi. Mukus saluran pernafasan merupakan cairan kental yang dikeluarkan dengan bikarbonat oleh sel-sel mukus tertentu yang normalnya dibentuk sekitar 100 $\mathrm{ml}$ dalam saluran napas setiap hari. Ketika terbentuk mukus yang berlebihan, maka proses normal pembersihan saluran pernapasan menjadi tidak efektif lagi, sehingga mukus tertimbun. Bila hal ini terjadi, maka membrane mukosa terangsang dan mukus ini dibatukkan keluar sebagai sputum atau tetap menghalangi saluran napas (Price dan Wilson,1984). 
Aktivitas mukolitik ditandai dengan penurunan kekentalan mukus pada penderita batuk atau asma. Aktivitas ini telah ditemukan pada berbagai tanaman yang dijadikan obat pengencer dahak seperti kombinasi Daun Kemangi dan Ekstrak Etanol Daun Sirih Merah yang diketahui memiliki aktivitas mukolitik (Neng Fisheri Kurniati, 2018).

Pada penelitian ini cairan mukosa intestinal menjadi fokus yang dijadikan bahan uji penelitian. Cairan mukosa intestinal atau mukus yang berwarna kuning kecoklatan yang kental tersebut diambil dari usus sapi untuk dilakukan uji mukositas. Pemilihan mukus usus sapi sebagai bahan uji pada penelitian ini dikarenakan mukus tersebut memiliki kesamaan komposisi dengan mukus manusia (Indrawati, et al., 2009). Mukus diduga dapat mengalami penurunan kekentalan apabila ditambahkan teh bunga telang yang mana didalamnya terkandung bahan-bahan yang memiliki aktivitas mukolitik.

Kembang telang merupakan tanaman yang jarang di gunakan sebagai alternatif pengobatan secara resmi serta masih kurang masif penelitian terkaitnya. Penggunaan bunga telang sebagai obat sendiri di Indonesia cenderung sebatas sebagai obat mata. Padahal bunga ini memiliki potensi untuk mengobati lebih banyak penyakit. Konon katanya kembang telang di Negara india bagian akarnya dapat digunakan sebagai obat bronchitis, TBC, asma, dan peradangan. Tidak hanya itu dari beberapa literature diketahui bahawa teh dari kembang telang ini dapat di gunakan sebagai obat batuk dan asma, namun belum ada penelitian lebih lanjut untuk membuktikannya.

Berdasarkan info yang kami dapat kami ingin mengembangkan penelitian untuk mengetahui potensi bunga telang sebagai obat pengencer dahak bagi penderita asma. Dipilihnya bunga telang dalam penelitian ini dikarenakan bunga telang yang mulai tren dikonsumsi masyarakat diindikasikan dapat mengencerkan dahak, selain itu penggunaan bunga telang sebagai obat pengencer dahak belum diketahui secara luas dan belum terdapat penelitian yang valid. Dari sini peneliti ingin melakukan uji aktivitas antimukolitik dari tanaman telang pada sampel.

Berdasarkan latar belakang tersebut maka judul penelitian yang kami ambil adalah Potensi Teh Bunga Telang (Clitoria Ternatea) Sebagai Alternatif Obat Pengencer Dahak Bagi Pengidap Asma Melalui Uji Mukositas

\section{METODE PENELITIAN}

Penelitian ini dilakukan dengan metode penelitian eksperimen untuk menentukan aktivitas mukolitik dari Teh Bunga Telang (Clitoria ternatea). Substrat yang digunakan pada penelitian ini ialah mukus yang berasal dari usus halus sapi segar karena banyaknya kesamaan dengan mukus manusia sebagaimana dijelaskan pada bagian tinjauan pustaka. Adapun Teh Bunga Telang merupakan sampel yang akan ditambahkan pada substrat untuk diuji aktivitas mukolitiknya. Pengujian dilakukan dengan alat ukur berupa Viskometer Oswald.

Penelitian ini memiliki sejumlah tahapan yaitu persiapan bahan, pembuatan Teh Bunga Telang, uji Mukolitik, serta perhitungan dan analisis hasil. Untuk melakukan tahapan-tahapan tersebut diperlukan sejumlah alat, antara lain termometer, aerometer, viskometer atau rangkaian alat uji viskositas, pemanas bunsen, gelas kimia, gelas ukur, dan batang pengaduk.

Pada tahap persiapan bahan disiapkan bahan untuk Teh Bunga Telang serta mukus sapi yang akan digunakan. Persiapan dilakukan dengan proses pengambilan bunga telang, penyortiran bunga telang, pencucian bunga telang, dan pengeringan bunga telang. Untuk penyiapan mukus sapi dilakukan pengambilan mukus dari usus sapi segar dengan cara dikeruk menggunakan sendok lalu diletakkan dalam wadah bersih tertutup.

Pada tahap pembuatan Teh Bunga Telang diambil sampel bunga telang yang telah dikeringkan untuk dilarutkan dengan air panas. Air seduhan teh ini yang akan digunakan untuk menguji aktivitas mukolitik dari teh bunga telang.

Pada tahap uji mukolitik diukur viskositas mukus dari mukosa usus sapi. Viskositas awal mukus yang digunakan diukur dengan viskometer atau dengan melakukan percobaan menggunakan rangkaian alat uji viskositas. Uji viskositas dapat dilakukan dengan membandingkan hasil pengukuran waktu (t) dan rapat massa $(\rho)$ cairan terhadap waktu dan rapat massa cairan pembanding yang telah diketahui viskositasnya. Adapun rumus yang digunakan untuk menghitung viskositas adalah. 


$$
\frac{\eta}{\eta_{0}}=\frac{t \times \rho}{t_{0} \times \rho_{0}} \text { atau } \eta=\eta_{0} \frac{t \times \rho}{t_{0} \times \rho_{0}}
$$

Sumber : (Halliday \& Resnick, 2010)

Uji viskositas dilakukan mengikuti persamaan poisuelle dengan membandingkan waktu laju alir cairan sampel $\left(\mathrm{t}_{0}\right)$ dan rapat massa $\left(\mathrm{r}_{0}\right)$ (Giles, 1984). Metode Ostwald yang merupakan variasi dari metode Poisuelle digunakan untuk mengukur waktu laju alir sampel mukus awal dan akhir pada pengujian terkait aktivitas mukolitik Teh Bunga Telang. Metode ini dilakukan dengan memasukkan sejumlah cairan yang akan diuji ke dalam pipa $\mathrm{A}$, kemudian dengan dihisap menggunakan pipet filler, cairan uji dibawa ke pipa B hingga melewati garis m. Cairan uji dibiarkan mengalir bebas dan waktu diukur untuk cairan tersebut hingga melewati garis batas berikutnya (garis $n$ ).

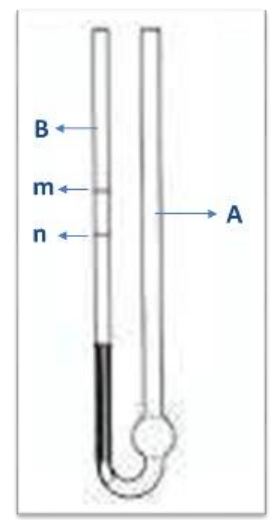

\section{Gambar 1. Skema Viskometer Ostwald}

(Sumber: Paramitha, Indah. 2014)

\section{HASIL DAN PEMBAHASAN}

\section{Pengukuran Konsentrasi Teh Bunga Telang}

Teh Bunga Telang diperoleh dengan melarutkan kelopak bunga telang dalam air panas kemudian diambil filtratnya. Bunga telang akan lebih mudah larut pada air dengan suhu mendidih sebagaimana seduhan teh pada umumnya. Sampel bunga telang sebanyak 5 buah kelopak (1,0 gram) diambil untuk dilarutkan dalam $250 \mathrm{ml}$ air mendidih. Campuran diaduk menggunakan batang pengaduk kaca hingga warna cairan berubah dari tak berwarna menjadi biru tua pekat dan didapatkan seduhan teh. 


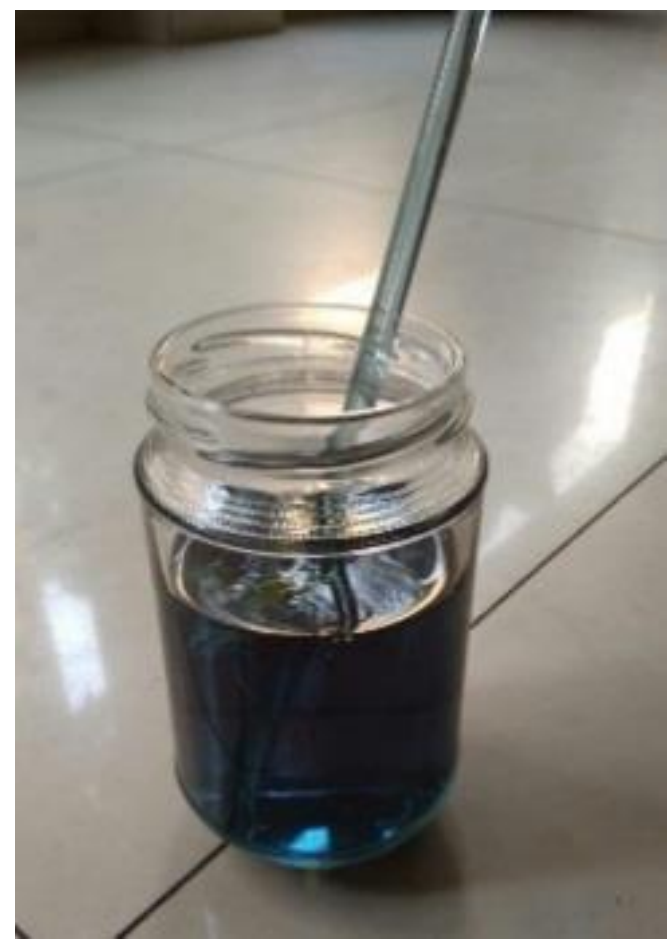

\section{Gambar 2. Seduhan Teh Bunga Telang}

(Sumber: Dokumentasi Peneliti)

Larutan didiamkan hingga suhunya turun menjadi suhu ruang $\left(25^{\circ} \mathrm{C}\right)$. Hal ini dilakukan guna membuat keadaan dimana suhu panas tidak memengaruhi penurunan viskositas dari substrat mukus usus halus sapi. Setelah mencapai suhu ruang, campuran disaring menggunakan penyaring teh untuk memisahkan larutan Teh Bunga Telang dari ampas bunga dan tangkainya. Larutan Teh Bunga Telang pekat tersebut digunakan sebagai larutan uji yang akan ditambahkan pada mukus.

\section{Pengumpulan Mukus Sapi}

Mukus sapi segar diambil melalui proses pengurutan usus halus dari sapi yang sudah dibersihkan dari kotoran maupun sisa makanan. Usus halus sapi untuk diambil mukusnya dikarenakan usus halus sapi lebih bersih dari kotoran dibandingkan usus besar. Usus dibelah secara vertikal, kemudian pada bagian dalam usus halus akan didapati tekstur serat otot usus yang berbentuk silindris memanjang dengan dilapisi lendir. Lendir pada bagian dalam usus halus merupakan mukus yang menjadi bahan penelitian ini. 


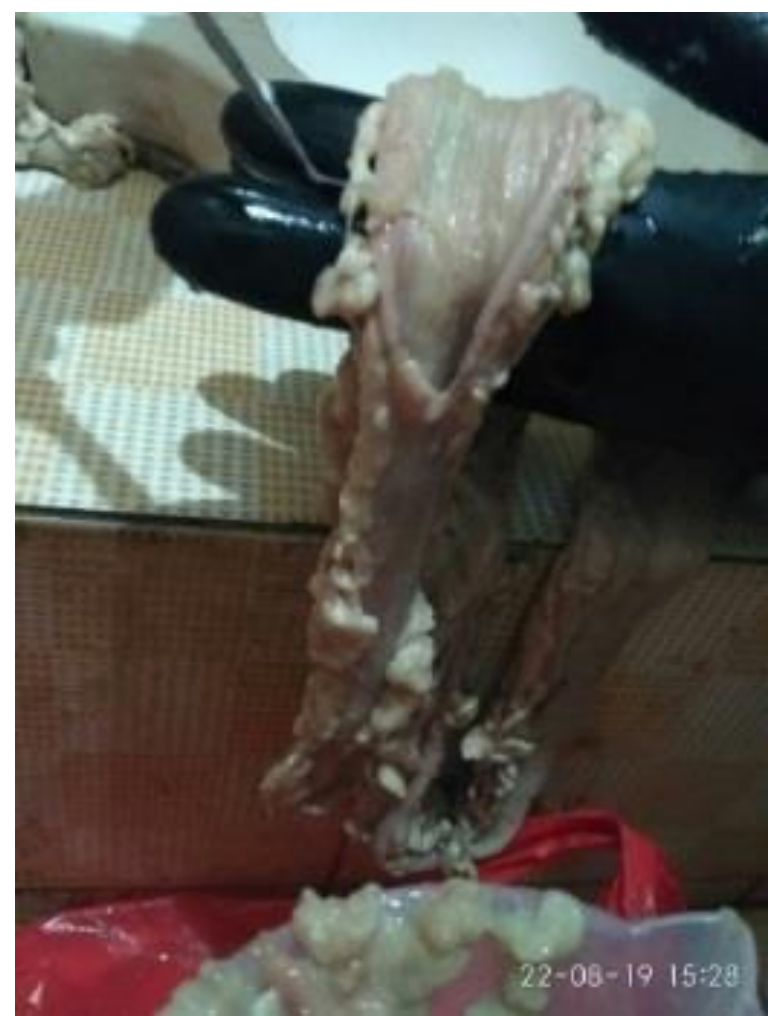

Gambar 3. Bagian Dalam Usus Sapi Segar

(Sumber: Dokumentasi Peneliti)

Mukus diambil perlahan dengan menggunakan sendok. Proses pengambilan mukus ini dilakukan dengan perlahan untuk meminimalisir terbawanya serat otot halus dari bagian dalam usus halus sapi. Hasil mukus yang diperoleh ialah cairan kental atau lendir berwarna kuning seulas dengan adanya sedikit potongan jaringan otot halus terbawa. Oleh karena adanya jaringan otot halus yang terbawa maka dekantasi perlu dilakukan agar tidak ada pengotor yang mengganggu laju alir dari mukus.

Mukus yang diperoleh didekantasi atau dipisahkan dari gumpalan jaringan usus halus yang terbawa dengan menggunakan jarum suntik. Dekantasi terhadap sampel mukus yang didapat tidak dilakukan menggunakan pipet, melainkan menggunakan jarum suntik. Pemisahan dengan pipet akan menyulitkan karena diameter pipet yang terlalu besar, sedangkan apabila menggunakan kertas saring lama waktu pemisahan dapat membuat mukus terkontaminasi dengan udara. Jarum suntik dipilih karena memiliki diameter lubang yang lebih kecil dari pipet sehingga dekantasi dapat dilakukan dengan lebih cepat dan mudah. Persiapan mukus ini harus dilakukan dengan segera karena rentan terkontaminasi bakteri, pengotor, hingga bereaksi dengan udara yang dapat menyebabkan berkurangnya kadar air dari mukus dan kekentalannya bertambah.

\section{Pengukuran laju alir mukus}

Mukus yang telah diperoleh diencerkan menggunakan labu ukur untuk memudahkan pengukuran laju alir. Pada percobaan ini digunakan konsentrasi $20 \% v / v$ yakni $20 \mathrm{ml}$ mukus sapi yang diencerkan hingga $100 \mathrm{ml}$ dalam air. Pengenceran dilakukan dengan menjaga kontaminasi bahan dari udara maupun faktor lain yang dapat mengubah sampel uji yang digunakan.

Mukus sapi yang telah diencerkan kemudian dilakukan pengukuran terhadap laju alir dengan menggunakan viskometer Ostwald. Pengukuran dilakukan sebanyak tiga kali sehingga diperoleh data yang akurat. Dari ketiga pengukuran yang dilakukan kemudian diambil rerata untuk hasil uji. Adapun hasil percobaan terhadap waktu laju alir mukus dapat dilihat pada Tabel 1. 
Tabel 1. Hasil Pengukuran Waktu Laju Alir Mukus Dengan Penambahan Air

\begin{tabular}{ll}
\hline Pengukuran ke- & Waktu Alir $(s)$ \\
\hline 1 & 22.49 \\
2 & 25.33 \\
3 & 26.86 \\
\hline Rata-rata & 24.89 \\
\hline
\end{tabular}

(Sumber: data penelitian peneliti)

Data yang diperoleh mengalami sedikit kenaikan dimungkinkan akibat adanya gumpalan jaringan usus halus yang terbawa setelah penyaringan. Walaupun telah dilakukan dekantasi, masih terdapat gumpalan yang berukuran lebih kecil dari diameter viskometer. Selain dari adanya gumpalan, mukus yang terkontaminasi udara dapat mengalami kenaikan kekentalan secara perlahan-lahan.

Berdasarkan data hasil pengukuran waktu laju alir mukus dengan penambahan air didapat dasar ukuran waktu laju alir awal dari mukus usus halus sapi. Data ini kemudian dibandingan dengan data waktu laju alir akhir dari mukus usus halus sapi.

Mukus yang telah diencerkan kemudian ditambahkan larutan teh bunga telang. Campuran yang digunakan pada percobaan ini memiliki konsentrasi sebesar $30 \% \%$ yakni dengan memasukkan 30 $\mathrm{ml}$ teh bunga telang kemudian menambahkan mukus sapi sampai batas pengenceran labu ukur 100 ml. Konsentrasi pada penelitian ini digunakan sesuai dengan konsentrasi mukus optimum dari penelitian terdahulu. Konsentrasi perbandingan mukus sapi dan sampel yang memiliki aktivitas mukolitik paling baik yakni pada konsentrasi sebesar 30\% $/ v$ (Astuti, 2002)

Tabel 2. Hasil Pengukuran Waktu Laju Alir Mukus Sapi Setelah Penambahan Teh Bunga Telang

\begin{tabular}{ll}
\hline Pengukuran ke- & Waktu Alir (s) \\
\hline 1 & 5.17 \\
2 & 7.45 \\
3 & 9.88 \\
\hline Rata-rata & 7.5 \\
\hline
\end{tabular}

(Sumber: data penelitian peneliti)

Hasil data pada tabel 4.1 memperlihatkan waktu laju alir yang lambat untuk mukus sapi tanpa penambahan teh bunga telang. Hasil pengukuran untuk mukus sapi setelah penambahan dapat dilihat pada tabel 4.2, dimana hasil waktu laju alir mengalami penurunan.

\section{Pembahasan Hasil Penelitian}

Hasil yang diperoleh dari pengukuran waktu laju alir dari mukus sapi sebelum dan sesudah penambahan teh bunga telang ialah waktu laju alir sesudah penambahan teh bunga telang mengalami kenaikan. Dari data dapat diketahui rerata waktu laju alir awal sebesar $24.89 \mathrm{~s}$ dan rerata waktu laju alir akhir sebesar $7.5 \mathrm{~s}$. Penurunan yang terjadi sebesar $69.87 \%$ dari waktu laju alir awal.

Viskositas sebagaimana yang dirumuskan oleh Halliday dan Resnick (2010) berbanding lurus dengan waktu laju alir dan massa jenis zat. Rumus penghitungan viskositas dapat ditulis sebagai berikut: 


$$
\frac{\eta}{\eta_{0}}=\frac{t \times \rho}{t_{0} \times \rho_{0}} \text { atau } \eta=\eta_{0} \frac{t \times \rho}{t_{0} \times \rho_{0}}
$$

Ketika waktu laju alir dari sampel mengalami penurunan maka akan menunjukkan bahwa viskositas atau kekentalan dari sampel zat cair mengalami penurunan. Sedangkan untuk massa jenis akan bernilai tetap selama tetap pada keadaan STP (Standard Temperature and Pressure). Sehingga sesuai dengan data yang diperoleh dimana terjadi penurunan waktu laju alir, dapat dikatakan pula bahwa viskositas dari sampel menurun setelah perlakuan penambahan teh bunga telang.

Penurunan viskositas mukus akan mengurangi penyempitan pada saluran napas dan mengurangi sesak napas pada penderita asma. Hal ini sesuai teori dimana penyempitan saluran napas pada penderita asma terjadi karena sekresi mukus yang berlebihan yang kemudian mengental akibat adanya mikroorganisme atau substan asing yang masuk dalam saluran napas (Rohman, 2015). Mukus berlebih yang mengalami pengenceran akan lebih mudah larut dalam sistem tubuh dan akan lebih mudah tereksresi atau keluar dari tubuh bersamaan dengan zat sisa pencernaan lainnya.

Dengan penurunan viskositas yang diakibatkan oleh penambahan teh bunga telang pada mukus berarti konsumsi teh bunga telang secara rutin akan memberikan efek. Penderita asma yang mengonsumsi teh bunga telang akan mengalami penurunan viskositas mukus pada saluran napas, sehingga berangsur akan kembali pada viskositas mukus manusia normal. Ketika mukus saluran napas mengalami pengenceran, maka penyempitan saluran pernapasan akan berkurang dan penderita asma dapat bernapas dengan lebih leluasa.

\section{KESIMPULAN}

Berdasarkan data hasil uji coba yang dilakukan menggunakan Viskometer oswald pada penelitian Potensi Teh Bunga Telang (Clitoria Ternatea) Sebagai Alternatif Obat Pengencer Dahak Bagi Pengidap Asma Melalui Uji Mukositas dapat ditarik kesimpulan bahwa larutan teh telang memiliki potensi aktivitas mukolitik pada konsentrasi $30 \% v / v$ sehingga konsumsi rutin berpotensi dapat membantu mengencerkan dahak pada penderita asma. Hal ini dikarenakan terdapat penurunan laju alir mukus setelah penambahan larutan teh bunga telang serta terdapat kesamaan antara mukus sapi dengan dahak manusia.

\section{REFERENSI}

Andriani, S., 2016. Ini Teh Biru dari Bunga Telang Lagi Tren di Inggris. [Online] Available at: https://www.lifestyle.okezone.com/amp/2016/08/22/298/1469762/.

Astuti, L. R., 2002. Penurunan viskositas relatif mukus sapi oleh perasan buah belimbing wuluh (Averrhoa bilimbi L.) Secara In Vitro. Thesis. Fakultas Farmasi. Universitas Sanata Darma.

Budiasih, K. S., 2017. Kajian Potensi Farmakologis Bunga Telang (Clitoria ternatea). Prosiding Seminar Nasional Kimia UNY: 201-206.

Dalimartha, S., 2008. Atlas Tumbuhan Obat Indonesia. Jakarta: Wisma Hijau.

Giles, R. V., 1984. Mekanika Fluida dan Hidaulika. Jakarta: Erlangga.

Halliday, D. \& Resnick, R., 2010. Fisika Dasar. Jakarta: Erlangga.

Mehta, A. \&. A. B., 2008. Investigation Into the Mechanism of Action of Moringa oleifera for its Anti-asthmatic Activity. Oriental Pharmacy and Experimental Medicine, 8(1): 24-31. 
Rizki, M. I. \& Hariandja, E. M., 2015. Review: Aktivitas Farmakologi, Senyawa Aktif dan Mekanisme Kerja Daun Salam (Syzygium polyanthum). Prosiding Seminar Nasional \& Workshop "Perkembangan Terkini Sains Farmasi \& Klinik 5".

Rohman, D., 2015. Effektivitas Latihan Nafas Dalam (Deep Breathing Exercise) Terhadap Peningkatan Arus Puncak Ekspirasi (APE) Pada Pasien Dengan Asma di Puskesmas 1 Rakit Kabupaten Banjarnegara. Doktoral Dissertation. Thesis. Purwokerto: Universitas Muhammadiyah Purwokerto. 